\title{
Bourse de voyage pour le Congrès conjoint Acsp/Sqsp
}

Acsp/Sqsp-Congrès conjoint, Québec, 29 juillet-1 ${ }^{\text {er }}$ août 2000

L'Association canadienne de science politique reçoit une subvention du Conseil de recherches en sciences humaines du Canada pour aider les membres des régions éloignées à assister au congrès. Ces fonds, qui sont surtout destinés aux membres les moins établis, seront répartis d'ici le 29 février 2000; ils seront alloués sur une base proportionnelle aux personnes qui en font la demande et qui remplissent les cinq critères suivants :

(1) Elles doivent avoir été membres de l'Association canadienne de science politique depuis les deux dernières années précédant la demande de bourse.

(2) Elles doivent présenter une communication lors du congrès (une bourse par communication).

(3) Elles doivent: (a) être membres non permanents d'un corps professoral; ou (b) être inscrits au moins en troisième année d'un programme de doctorat; ou (c) avoir reçu leur doctorat au cours des cinq dernières années et ne pas occuper en ce moment un poste à temps plein.

(4) Les bourses de voyage seront accordées aux personnes qui n'en ont pas reçu une l'année prédédente.

(5) Une bourse de voyage peut seulement être consentie aux personnes qui enseignent (dans le cas de 3[a]) ou qui étudient ou résident (dans le cas de 3[b]) ou qui résident (dans le cas de 3[c]) à plus de 500 $\mathrm{km}$ du lieu où se déroulera le congrès.

Prière d'adresser toute demande de bourse de voyage au secrétaire-trésorier, Association canadienne de science politique, bureau 204, 260, rue Dalhousie, Ottawa (Ontario) K1N 7E4, d'ici le 15 février 2000. Les formulaires de demande sont disponibles au bureau de l'Association (téléphone: 613-562-1202; télécopieur: 613-241-0019; courrier électronique : cpsa@csse.ca). 
The Canadian Political Science Association is pleased to award the / L'Association canadienne de science politique a l'honneur de décerner le

\section{VINCENT LEMIEUX PRIZE / PRIX VINCENT-LEMIEUX}

for / pour 1999

to / à

\section{Jean-Rodrique Paré}

Queen's University

for his thesis / pour sa thèse

\section{La nation, la culture et la science. Les visages de l'engagement dans l'oeuvre de Max Weber}

The Vincent Lemieux Prize, named after the eminent political scientist Professor Vincent Lemieux of the Université Laval, is awarded to the author of the best $\mathrm{PhD}$ thesis submitted at a Canadian university in 1997 or 1998, in English or in French, in any subfield of political science and judged eminently worthy of publication in the form of a book or articles. A jury of eminent political scientists, appointed by the Board of Directors of the Canadian Political Science Association, makes the selection.

The Vincent Lemieux Prize has been established with a grant from the Presses de l'Université de Montréal. In addition to the honour, the 1999 award includes a monetary prize in the amount of $\$ 750$.

Le Prix Vincent-Lemieux, qui doit son nom à un éminent politologue, le professeur Vincent Lemieux de l'Université Laval, est décerné à l'auteur, homme ou femme, de la meilleure thèse de doctorat en science politique soumise, en anglais ou en français, à une université canadienne en 1997 ou en 1998, thèse qui, par son excellence, mérite d'être publiée sous la forme d'un livre ou d'articles. Un jury de politologues éminents, nommés par le Conseil d'administration de l'Association canadienne de science politique, fait le choix de la thèse.

Le Prix Vincent-Lemieux a été créé grâce à une subvention des Presses de l'Université de Montréal. En plus du prestige associé au Prix, le lauréat de 1999 reçoit la somme de $750 \$$. 